\title{
Financial Risks and their Management in the Mining Industry
}

\author{
Viktoriia Frolova ${ }^{1, *}$ Olga Glinkina $^{2}$, and Tatyana Shpilkina ${ }^{3}$ \\ 1 "Financial University under the Government of the Russian Federation" (Financial University), \\ 125993 Leningradsky av., 49, Moscow, Russia \\ ${ }^{2}$ Russian New University, 105005 Radio st., 22, Moscow, Russia \\ ${ }^{3}$ Moscow Automobile and Road Construction State Technical University (MADI), 125319 \\ Leningradsky av., 64, Moscow, Russia
}

\begin{abstract}
The authors investigated the issues of assessing financial risks in the mining industry, studied the problems of hedging risks in conditions of high uncertainty when a company enters foreign markets. The importance of the SPIC document was determined as a form of interaction between enterprises and the state, which allows more actively investing in the mining industry, while reducing risks for investors. The article outlines the issues of digitalization that allow managing financial risks, based on biogeography in order to optimize the rules for mining, as well as a system of classification rules (CRI) for a qualitative and quantitative approach in predicting bankruptcy and analyzing credit risk.
\end{abstract}

\section{Introduction}

Modern conditions for the functioning of mining companies are aggravated by the instability of the external processes of entrepreneurship. The main factors causing operating risks are the fluctuates of Bank of Russia rates (in April 2021 discount rate was increased by $0.5 \%$ to $5 \%$ ), interest rates on loans, oil prices, exchange rates, inflation, stock market indices. The most significant impact in recent years has been provided by sanctions, various kinds of international events, and last year exacerbated the problems with the introduction of measures related to COVID-19. In addition, many mining entrepreneurs note the instability of the legislative framework, the presence of a significant amount of insider information, mergers and acquisitions of companies. The above mentioned factors predetermine financial risks, both for individual transactions and contracts, and for companies as a whole, including mining entities. Cyclic financial crises also affect the financial state and performance of mining companies [1].

The mining industry today has a significant impact on the world economy, being a key factor not only for economic growth, but also for social development in a set of countries rich with natural resources, starting from the regional level of spatial development [2]. In terms of the level of capitalization of large companies in the industry, it is in fifth place, after the banking sector and a number of industrial sectors: IT, oil and gas, pharmaceuticals. To implement effective management of the economies of resource extracting countries, it is

* Corresponding author: academy@,fa.ru 
necessary to rationalize the system of government regulation of subsoil use by mining industry. At the same time, it should be noted that under the influence of scientific and technological progress, the mining industry is constantly undergoing changes associated with the improvement of the sectoral structure. This is reflected in the complexity of the relationships in it. It is possible to cite the following indicators characterizing the importance of industry for development among other sectors of global economy. The share of mining industry in world GDP is about one third (about $\$ 10$ trillion), and the indicators for the structure of the economically active population are $1 / 5$, that is, about $17 \%$ of the world's population.

The mining industry has always been associated with major investments and a high level of risk, and this is due to its specifics. This industry is associated, first, with the risks of mining and geological processes as the deposit is developed. It is important that all projects in the mining industry are long-term, costly with an investment cycle over many years. Of course, this forces the company to resort to the use of borrowed funds, which can increase the risks of fulfilling the company's obligations. Hence, it follows that the most interested party should be the state, since it depends on the mineral resource sector, which generates income through the activities of mining enterprises.

\section{Materials and Methods}

Russian enterprises engaged in the extraction of minerals, in parallel, carry out activities for the export of mineral components to the world market. The global foreign exchange market is now extremely unstable, and not only because of the COVID-19 pandemic. In the past 5 years, the foreign exchange market has suffered for many reasons, which include oil prices instability, trade war between the United States and China, global unrest, elections in the United States, etc. Currency volatility is especially significant for Russian companies, since the total share of mineral resources in the national export is almost $80 \%$.

Another characteristic factor for mining enterprises is the instability and constant fluctuations of prices in the mineral raw materials market, which affects the investment efficiency, the ability of mining companies to function productively in a competitive environment. The basis of prices for concluding long-term contracts is formed by prices in centralized markets, such well-known financial centers as New York, London, and Tokyo. It is here that prices for non-ferrous and precious metals are set. Products such as coal and iron ore do not have centralized trading floors. Thus, the price of goods in the primary sector of the economy in the world is characterized by inconsistency (cyclicality) and volatility, and this creates high price market risks for both producers and consumers.

Research carried out by IMF analysts has revealed the peculiarities inherent in price cycles: a sharp jump of prices from the phase of the rise to the phase of the decline; the recession phase is often longer than the upturn phase (asymmetric price cycle); stability for each phase does not exist, and the phase does not depend on the time period. The importance of understanding the cyclical period in relation to prices in mineral markets is great, because it determines the profitability of companies that depend on the export (import) of their products. In modern conditions, many manufacturing enterprises began to pay more attention to hedging price risks, but only at the stage of price decline. In contrast, consumers of the raw materials hedge price risks when prices rise sharply. Foreign exchange hedging can reduce the risks associated with foreign exchange market volatility, including reducing income volatility and protecting the value of future cash flows or asset values, in order to reduce the volatility of cash flows in the contract currency or the volatility of earnings in the reporting currency. This is especially important in purchase and sale of raw materials and finished products priced in foreign currency, in order to avoid an imbalance in the liabilities 
and assets of mining companies, both at the current time and in the future, fixing the exchange rates on the date of payment.

Commodity prices are characterized by such an indicator as volatility, which reflects the readings of short-term fluctuations in world prices. Over the past 30 years, price volatility in the global raw material market has increased significantly. In this regard, it should be borne in mind that the existing today very high dependence on the export of mineral resources, both for state and enterprises, as well as on the high volatility of prices for mineral goods, poses a problem with decision-making related to investments [3]. In this regard, there is an urgent need for mining and manufacturing enterprises, as well as for their consumers to be engaged in a comprehensive assessment of price risk, since if it is possible to reduce this type of risk. Therefore, it becomes important for enterprises to improve the efficiency of forecasting price risks, especially for companies that receive the main profit from export operations with raw materials. In addition, it is necessary to develop and apply multi-criteria models for making investment decisions using machine intelligence [4].

Let us consider the example of the Ozernaya Mining Company, which is developing a large deposit of polymetallic ores in Buryatia (the Eastern Siberia, Russia). The company received 9 billion rubles from VEB.DV (former Fund for the Development of the Far East and the Arctic). This is one of the largest projects financed by the foundation. The funds were provided in a single installment for 10 years at the interest rate of $2 \%$ per annum [5].

"The Ozernoye deposit is one of the ten best zinc deposits in the world in terms of reserves and ore quality. In addition to zinc, the ore contains lead, cadmium and silver. The metal content in the ore is as follows: $6.15 \%$ zinc, $1.2 \%$ lead, silver reserves are estimated at 4500 tons. The field was discovered back in the 1960s, but they did not start developing it for a long time, since there were no opportunities. In 2010, Metals of Eastern Siberia, a member of the Metropol Group, took over its development. It was assumed that by 2017 a mining and processing plant (GOK) will be built at the field, where 8 million tons of ore must be processed annually, giving 880 thousand tons of zinc concentrate and 108 thousand tons of lead" [6].

However, the plans, unfortunately, were not implemented: by 2019, only individual infrastructure facilities appeared at the field, and stripping work was carried out in the amount of about 1 million tons. In the spring of 2020, the Ozernaya Mining Company, established for this project, bought the license. In September 2020, at the Eastern Economic Forum, the company signed an agreement with VTB Bank on the provision of a loan in the amount of over 70 billion rubles. VEB.DV believes that the project for the construction of a mining and processing plant based on the polymetallic ores of the deposit has been recognized as a priority for financing. This project is of great importance for the development of the Far East, since it involves the organization of the largest production of zinc concentrate in Russia, which will create more than 1400 jobs, and in 10 years the GRP will increase by more than 125 billion rubles, and the Republic of Buryatia will receive more than 16 billion rubles of additional tax revenues. The enrichment of ore at this mining and processing plant will be carried out without the use of cyanides, which significantly improves the ecology of the project [6]. Considering that, this project will be financed from the state fund and only at $2 \%$, this will reduce the risks of implementing this project and entering the world market.

The present difficult period mining companies pass along with the whole world burst into with the pandemic, and demonstrate good resilience, skillful risk management, which allowes mining business entities remaining in a stable financial position by the results of 2020, despite the imbalance in the commodity market. The pandemic has driven up costs, but has created opportunities for innovation. In the future, according to experts, it is financial stability, combined with effective strategic planning, that will create advantages over other industries. 


\section{Results and Discussion}

It should be noted that the complication of the mining process, sharp fluctuations in raw material prices are primarily associated with the disruptions in supply chains, instability in demand due to economic uncertainty and the introduction of a number of procedures and protocols caused by restrictions due to COVID-19. Therefore, only an integrated approach, including cost management, performance management of all links of the value chain, will help companies to survive. It is necessary to focus on the productivity gains achieved during the quarantine period and remove processes that lead to reduced productivity or increased costs. In general, the forecasts of experts call for the adoption of well-thought-out strategic decisions focused on the ongoing changes associated with unprecedented price volatility, appearance of substitute goods, and the volatility of consumer demands.

The most significant consequences of the COVID-19 pandemic are supply disruptions, the inability to determine the demand for commodities, so it is important for mining companies to take appropriate measures considering a whole range of factors (Fig. 1).

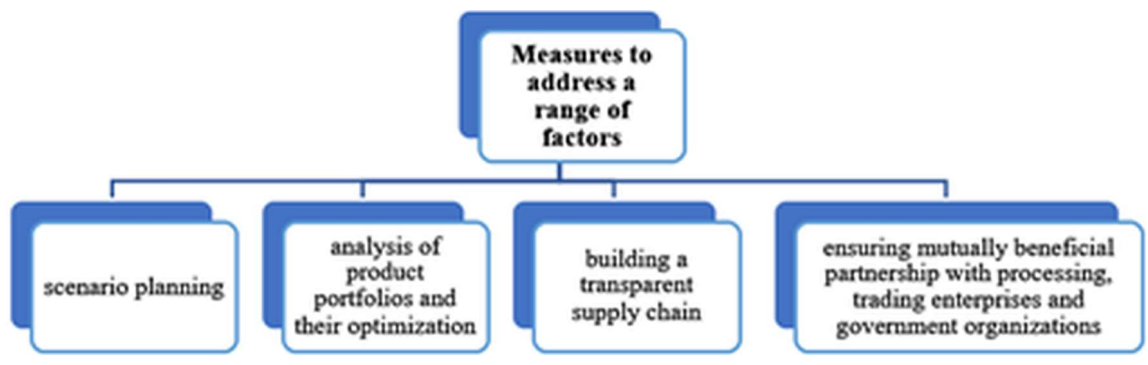

Fig. 1. Measures taken by mining companies to address the range of negative factors.

On April 1, 2020, the Federal Law "On the Protection and Encouragement of Investment in the Russian Federation" was adopted. Despite the fact that all the provisions of the law came in force on April 1, it is not yet active. This is due to the fact that it is necessary to adopt a number of bylaws [7] to clear the status of the Agreements on the Protection and Promotion of Investments, according to which the state guarantees the investor that it will not apply acts that worsen the conditions for the implementation of the project. An important document for investors is the SPIC (agreement between the investor and the state, which fixes the obligations of the parties).

The main provisions of the Special Investment Contract (SPIC) are as follows:

- the investor undertakes, within the time period stipulated by the contract, to implement an investment project for the introduction or development and implementation of technology in order to master the serial production of industrial products based on this technology on the territory of the Russian Federation, investing its own and (or) borrowed funds in the project; - the state (jointly the Russian Federation, and the constituent entity of the Russian Federation, and the municipality) undertakes, within the limits of its powers, to ensure the stability of the conditions for conducting economic activities in the industrial sector provided for by the SPIC [6].

The SPIC was established in 2014 as a tool to encourage investors to develop industrial production in the country. In 2019, SPIC 1.0 was modernized into a new one - SPIC 2.0, for development and transfer of technologies to the Russian industry [6]. This form of interaction between enterprises and the state will make it possible to more actively invest in the mining industry, but also in the others, while reducing the risks for investors.

The size, timing and form of support (SPIC) are shown in Table 1. 
Table 1. Size, timing and form of support for the Special Investment Contract (SPIC).

\begin{tabular}{|c|c|}
\hline Support size and timing & Support form \\
\hline $\begin{array}{l}\text { 1. SPIC term: } \\
\text { - no more than } 15 \text { years for a project up to } 50 \text { billion } \\
\text { rubles; } \\
\text { - no more than } 20 \text { years for a project with a volume } \\
\text { of } 50 \text { billion rubles. }\end{array}$ & $\begin{array}{l}\text { 1. Stability of the business environment for } \\
\text { the investor. }\end{array}$ \\
\hline $\begin{array}{l}\text { 2. Support under the SPIC is valid until the tax and } \\
\text { non-tax budget expenditures in relation to the project } \\
\text { do not exceed } 50 \% \text { of the capital investments under } \\
\text { the SPIC. }\end{array}$ & 2. Tax incentives. \\
\hline \multirow{3}{*}{$\begin{array}{l}\text { 3. The term of the SPIC may be extended by the } \\
\text { Government of the Russian Federation if the investor } \\
\text { is subject to restrictive measures established by a } \\
\text { foreign state. }\end{array}$} & $\begin{array}{l}\text { 3. Obtaining Made in Russia status for } \\
\text { products with a suspensive condition for } \\
\text { localization. }\end{array}$ \\
\hline & $\begin{array}{l}\text { 4. Access to government orders and } \\
\text { subsidiary support. }\end{array}$ \\
\hline & $\begin{array}{l}\text { 5. Creation of infrastructure by the } \\
\text { constituent entities of the Russian } \\
\text { Federation, special conditions for the lease } \\
\text { of land plots. }\end{array}$ \\
\hline
\end{tabular}

The President's Address to Parliament in April 2021 clearly reflects the state's initiatives for the development of regions based on the provision of infrastructure budget loans at a rate of no more than $3 \%$, with a maturity of 15 years. Until the end of 2023 , it is planned to allocate such loans for a total amount of at least 500 billion rubles. In addition, it is planned to restructure the debts of the regions, which includes the above-mentioned Republic of Buryatia. The planned restructuring amount for this region will be 131 million rubles. Such support is especially necessary for the regions in the current conditions.

The world economy today is in a period of uncertainties, price volatility in the commodity markets, which affects not only the rating of a number of major risks, but also the opening opportunities for mining companies in 2021. Many of the companies in this industry began a serious digital transformation of their business about 3 years ago, as new technologies accelerate the exploration of new deposits and reduce the costs of operating mines. In addition, digital technologies allow financial risk management, for example, by conducting a credit risk assessment based on biogeography in order to optimize mining rules [8], as well as a classification rule system (CRI) for a qualitative and quantitative approach in bankruptcy forecasting and analysis of credit risk [9].

Therefore, the task of attracting investment is associated, first, with artificial intelligence (AI) tools. For example, we can take the process of digitalization of the supply chain "pitmine-port", which will help to link operational processes, ensure their transparency and reduce costs. At the same time, it is necessary to assess financial risks, for example, in the online space based on an embedded web system and a data analysis algorithm [10-12].

To take full advantage of the new opportunities associated with digitalization, small mining companies must team up with industry leaders, since the mining, as already noted, is very capital intensive. This is happening now everywhere, all over the world - the creation of alliances, joint ventures, which not only form a new business structure, but also ensure the quality of corporate management, opportunities to reduce risks within the partner ecosystem. Start-up companies with promising fields are more likely to turn to large companies seeking to expand exploration [13-14]. As a result, big business gets access to new deposits, and small companies get access to their resources and technologies [15-16]. All this happens precisely 
because of the capital intensity of projects in the mining sector, associated with the complexity of mining, location in remote areas.

It is noted that the mood of investors in mining companies tends to change their attitude, demonstrating a greater understanding of the need to invest in infrastructure projects that do not directly generate profit.

\section{Conclusion}

Summing up the results of this study, let us make on the main conclusions.

The world economy today is in a period of uncertainties, price volatility in the commodity markets, which affects not only the rating of a number of major risks, but also the opening opportunities for mining companies in 2021.

Mining industry today:

- has a significant impact on the world economy, being a major factor not only for economic growth, but also for social development in a whole set of countries with rich natural resources;

- in terms of the level of capitalization of large companies in the industry, it is in fifth place, after the banking sector and a number of industrial sectors: IT, oil and gas and pharmaceuticals. To implement effective management of the economies of countries, it is necessary to rationalize the system of state regulation related to subsoil use in the mining industry;

- under the influence of scientific and technological progress, the mining industry is constantly undergoing changes associated with the improvement of the sectoral structure, and this is reflected in the complexity of the relationships in it;

- an important document for investors has become a document called SPIC (agreement between an investor and the state, which fixes the obligations of the parties). The SPIC was developed back in 2014 as a tool to encourage investors to develop industrial production in the country, while this form of interaction between enterprises and the state will allow more actively investing in the mining industry;

- the President's Address to Parliament in April 2021 clearly reflects the state's initiatives for the development of regions based on the provision of infrastructure budget loans at a rate of no more than $3 \%$, with a maturity of 15 years. Until the end of 2023 , it is planned to allocate such loans for a total amount of at least RUB 500 billion;

- the mining industry should make more active use of digital technologies that allow managing financial risks, for example, by conducting a credit risk assessment based on biogeography in order to optimize mining rules, as well as a classification rule system (CRI) for a qualitative and quantitative approach in forecasting bankruptcy and credit risk analysis.

Today, such an indicator as "social responsibility of business" is not just some kind of altruistic tendency; it is a tool for managing financial and reputational risks.

\section{References}

1. K. Fijorek, A. Jurkowska, I. Jonek-Kowalska, Resources Policy 70, 101965 (2021)

2. V. Frolova, O, Dolina, T. Shpilkina, E3S Web Conf. 41, 04027 (2018)

3. V. Frolova, O. Dolina, T. Shpilkina, E3S Web Conf. 105, 01054 (2019)

4. K.C. Cheng, M.-J. Huang, C.-K. Fu, K.-H. Wang, H.-M. Wang, L.-H. Lin, Sustainability (Switzerland) 13(6), 3100 (2021)

5. N. Ulianov, Expert 12(1199), 26-27 (2021)

6. N. Ulianov, Expert 6(1193), 36-40 (2021) 
7. Consultant Plus Server. URL: http://www.consultant.ru/

8. P.K. Giri, S.S. De, S. Dehuri, S.-B. Cho, Intel. Sys. Acc., Fin. Man. 4, 34-42 (2021)

9. J. Uthayakumar, T. Vengattaraman, P. Dhavachelvan, Journal of King Saud University - Computer and Information Sciences 32(6), 647-657 (2020)

10. Z. Cui, F. An, W. Zhang, Microproc. Microsys 82, 103898 (2021)

11. E. Dotsenko E., N. Ezdina. E3S Web Conf. 41, 04048 (2018)

12. O.V. Glinkina, S.A. Ganina, A.V. Maslennikova, T.A. Solostina, Int. J. Man. 11(3), 457466 (2020)

13. O. Miliushenko, A. Kovalev, M. Zhidkova, E3S Web Conf. 105, 04046 (2019)

14. O. Kalenov, S. Kukushkin, E3S Web Conf. 174, 02024 (2020)

15. S. Kukushkin, O. Kalenov, R. Kamanina, O. Kosareva, E3S Web Conf. 174, 04014 (2020)

16. E.Y. Dotsenko, N.P. Ezdina, A.S. Khasanova, M.I. Khasanov, E3S Web Conf. 247, 01069 (2021) 